\title{
UJI ORGANOLEPTIK DAN SIFAT KIMIA KUE SEMPRONG CAMPURAN TEPUNG UBI JALAR UNGU (IPOMOEA BATATAS) DAN TEPUNG TERIGU
}

\author{
Organoleptic Evaluation and Chemical Properties of Semprong Cookies made from \\ Purple Sweet Potato (Ipomea Batatas) and Wheat Flour \\ Olfita S Montolalu ${ }^{1)^{*}}$, Tineke Langi ${ }^{2)}$, dan Teltje Koapaha ${ }^{2)}$ \\ ${ }^{1)}$ Mahasiswa Program Studi Teknologi Pangan \\ ${ }^{2)}$ Dosen Program Studi Teknologi Pangan

\begin{abstract}
Jurusan Teknologi Pertanian Fakultas Pertanian Universitas Sam Ratulangi
Jl. Kampus UNSRAT Manado, 95115

*Email: opingmontolalu7@gmail.com
\end{abstract}

\begin{abstract}
The aim of this research is to produce a quality semprong cookies by mixing purple sweet potato flour and flour properly, based on the panelists' preference level and the nutritional characteristics of the "semprong" cake. The organoleptic test results of the "semprong" cake which are preferred in terms of color, taste, aroma and texture are treatment A (10g purple yam flour $+90 \mathrm{~g}$ wheat flour). The results of the proximate content analysis of "semprong" cakes for water content ranged from $3.16 \%-3.77 \%$, ash content ranged from $1.32 \%-2.09 \%$, fat content ranged from $16.26 \%$ $20.95 \%$, content protein ranges from $7.06 \%-8.95 \%$, carbohydrate content ranges from $66.31 \%-71.21 \%$.
\end{abstract}

Keywords : Semprong Cake, Purple Sweet Potato Flour, Wheat Flour

\section{PENDAHULUAN}

Ubi jalar ungu merupakan tanaman yang banyak dikonsumsi masyarakat Indonesia. Ubi jalar ungu mempunyai potensi sebagai bahan baku tepung mengingat kandungan karbohidratnya yang cukup tinggi. Pemanfaatan ubi ungu dalam bentuk tepung dapat mensubtitusikan tepung terigu sehingga dapat mengurangi ketergantungan akan tepung terigu yang cukup tinggi. Selain itu dapat memperluas penggunaanya menjadi berbagai bentuk olahan.

Pangan fungsional adalah makanan yang memberi manfaat bagi kesehatan, selain fungsinya sebagai zat gizi dasar (Silalahi2006). Ubi jalar ungu potensial dimanfaatkan sebagai bahan pangan

fungsional karena memiliki antosianin, pigmen yang menyebabkan daging umbi berwarna ungu, yang mempunyai aktivitas antioksidan. Zat warna antosianin pada ubi jalar ungu mempunyai aktivitas antioksidan lebih kuat. Senyawa antioksidan alami mampu memperlambat, menunda, ataupun mencegah proses oksidasi (Shahidi dan Naczk,1995). Kandungan antosianin pada ubi jalar ungu cukup tinggi, yaitu mencapai $519 \mathrm{mg} / 100 \mathrm{~g}$ 
berat basah (Kumalaningsi, 2008). Dengan demikian ubi jalar ungu mempunyai potensi besar sebagai sumber antioksidan alami dan sekaligus sebagai pewarna ungu alami (Pokorny $d k k$. 2001). Mengolah ubi jalar ungu menjadi tepung merupakan salah satu cara untuk penyimpanan dan pengawetan ubi jalar ungu. Ubi jalar ungu dalam bentuk tepung juga akan mempermudah pemanfaatannya sebagai bahan baku industri pangan maupun non-pangan (Menurut Murtiningsih \& Suyanti, 2011). Terigu adalah tepung atau bubuk halus yang berasal dari biji gandum, dan digunakan sebagai bahan dasar pembuat kue, mie, roti, dan pasta. Tepung terigu sebagian besar terdiri dari pati. Menurut Wayne (2013), tepung terigu memiliki sekitar 68$78 \%$ pati.

Kue "semprong" adalah kue tradisional yang dibuat dari bahan tepung terigu, telur, gula, susu bubuk, margarine dan santan. Mencermati banyaknya varian kue "semprong", hal ini menunjukkan bahwa kue "semprong" dapat dibuat dengan kombinasi berbagai macam campuran tepung, misalnya tepung ubi jalar ungu.

\section{METODE PENELITIAN}

\section{Bahan dan Alat}

Bahan yang digunakan dalam penelitian ini adalah Ubi jalar ungu yang berasal dari pasar Bersehati Manado, tepung terigu "Kompas", gula, santan kelapa, mentega, telur, kayu manis dan bahan-bahan kimia untuk analisis. Alat yang digunakan dalam penelitian ini adalah Pisau, oven, thermometer, grinder, slicer, wadah plastik, beker glass, gelas ukur, timbangan analitik, saringan/ayakan, stopwatch, kompor, panci, toples, cetakan semprong.

\section{Rancangan Penelitian}

Metode penelitian yang digunakan adalah Rancangan Acak Lengkap (RAL) pada 5 perlakuan dengan ulangan sebanyak 3 (tiga) kali untuk masingmasing perlakuan.

Campuran tepung ubi jalar ungu dan tepung terigu dengan perbandingan sebagai berikut :

$\mathrm{A}=10 \%$ tepung ubi jalar ungu : $90 \%$ tepung terigu

$\mathrm{B}=30 \%$ tepung ubi jalar ungu : $70 \%$ tepung terigu

$\mathrm{C}=50 \%$ tepung ubi jalar ungu : $50 \%$ tepung terigu

$\mathrm{D}=70 \%$ tepung ubi jalar ungu : $30 \%$ tepung terigu

$\mathrm{E}=90 \%$ tepung ubi jalar ungu : $10 \%$ tepung terigu

\section{Pembuatan Tepung Ubi Jalar Ungu}

Ubi jalar ungu dikupas dan dicuci hingga bersih dari sisa-sisa tanah yang menempel, kemudian diblancing selama 3 menit dengan uap pada suhu $100^{\circ} \mathrm{C}$. Setelah itu ubi jalar ungu didinginkan kemudian di iris tipis-tipis menggunakan slicer dengan ketebalan $0,1 \mathrm{~cm}$. Setelah itu irisan daging ubi jalar ungu diletakan diatas wadah dan dikeringkan dengan menggunakan cahaya matahari. Irisan ubi jalar ungu yang sudah kering kemudian dihaluskan dengan menggunakan grinder. Bubuk daging ubi jalar ungu yang telah dihaluskan kemudian diayak dengan menggunakan ayakan tepung.

\section{Pembuatan Kue "Semprong”}

a) Tahap pencampuran

Pertama campurkan 1 butir telur, gula 100 gr, mentega 10 gr, susu bubuk 20 gr dan kayu manis 1 sendok teh, aduk sampai merata. Kemudian tambahkan tepung ubi ungu dan tepung terigu sesuai perlakuan, aduk sampai semua bahan tercampur dan kemudian tambahkan santan kelapa 1 gelas, aduk sampai adonan berbentuk krim.

b) Tahap pencetakan adonan

Tahap ini lebih tepatnya adonan yang sudah jadi sebelumnya panaskan 
cetakan kue semprong, setelah panas tuang 1 sendok makan adonan ke dalam cetakan lalu dijepit, tunggu 2 menit setelah adonan agak kering lalu dibentuk dengan cara menggulung.

\section{HASIL DAN PEMBAHASAN}

\section{Sifat Organoleptik Warna}

Hasil uji organoleptik terhadap warna kue semprong campuran tepung ubi jalar ungu dan tepung terigu berkisar antara 3,56 - 4,00 (suka) dapat dilihat pada Gambar 1.

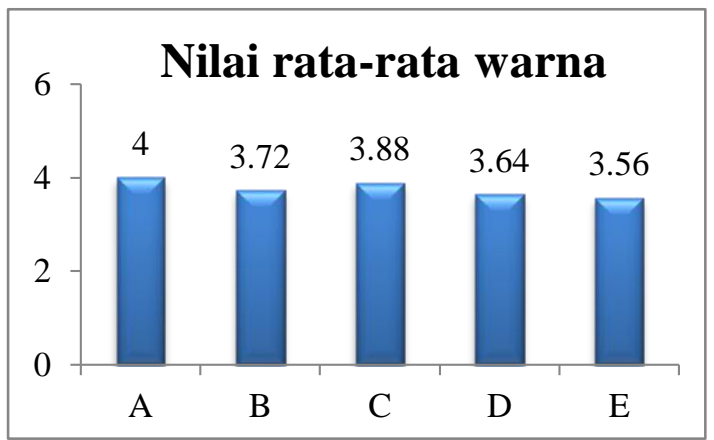

Gambar 1. Nilai rata-rata uji organoleptik terhadap warna kue semprong

Hasil penelitian terhadap tingkat kesukaan panelis pada warna kue semprong dengan pencampuran tepung ubi jalar ungu dan tepung terigu tidak memberi pengaruh nyata pada warna kue semprong. Warna yang dihasilkan kue semprong dengan pencampuran ubi jalar ungu dan tepung terigu adalah berwarna coklat muda sampai coklat ungu tua.

Penentuan mutu suatu bahan pangan pada umumnya tergantung pada warna, karena warna tampil terlebih dahulu (Winarno, 2004). Warna ungu pada tepung ubi ungu dikarenakan senyawa anthosianin. Anthosianin merupakan pigmen yang dapat memberikan pewarna alami yang terdapat pada kulit dan daging ubi yang berwarna ungu kehitaman atau ungu pekat (Richana 2012) sehingga semakin banyak jumlah tepung ubi ungu dalam kue semprong maka warnya semakin pekat. Selain itu perubahan warna juga disebabkan adanya proses karamelisasi gula yang terdapat dalam bahan tambahan kue semprong.

\section{Aroma}

Hasil uji organoleptik terhadap aroma kue semprong campuran tepung ubi jalar ungu dan tepung terigu berkisar antara 3,93 - 4,08 (netral sampai suka) dapat dilihat pada Gambar 2.

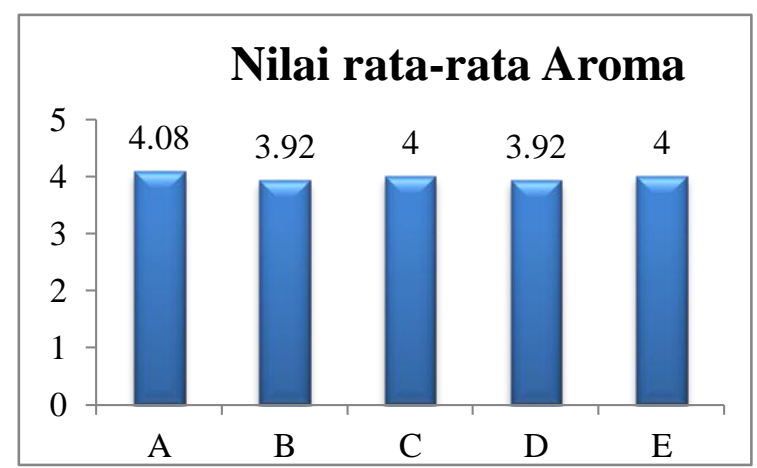

Gambar 2. Nilai rata-rata uji organoleptik terhadap aroma kue semprong

Berdasarkan hasil analisis sidik ragam kue semprong dengan pencampuran tepung ubi ungu dan tepung terigu menunjukan nilai $\mathrm{F}$ hitung lebih kecil dari nilai $\mathrm{F}$ tabel hal ini menunjukan pencampuran tepung ubi jalar ungu dan tepung terigu tidak memberikan pengaruh terhadap aroma kue semprong. Aroma kayu manis yang ditambahkan dalam adonan kue semprong dapat menutupi aroma dari tepung ubi jalar ungu dan tepung terigu sehingga tidak menimbulkan aroma tertentu karena dalam kayu manis memiliki kandungan zat minyak atsiri. Menurut Wijayanti $d k k$ (2010), minyak atsiri merupakan salah satu senyawa aromatik sebagai metabolit (sekunder) yang mudah menguap. Penggunaan bahan lain yang berupa santan juga mempengaruhi. Menurut Harijono (2012), santan memiliki senyawa nonylmethylketon yang bersifat mudah menguap, sehingga ketika dipanaskan akan menimbulkan aroma yang khas kelapa yang harum. 
Aroma adalah bau yang sukar diukur sehingga menimbulkan pendapat yang berlainan dalam menilai kualitas. Perbedaan pendapat disebabkan karena tiap orang mempunyai perbedaan kemampuan indera penciuman, meskipun mereka dapat membedakan aroma namun setiap orang mempunyai kesukaan yang berlainan (Kartika, 1998).

\section{Tekstur}

Hasil uji organoleptik terhadap tekstur kue semprong campuran tepung ubi jalar ungu dan tepung terigu berkisar antara 4,04 - 4,28 (suka), dapat dilihat pada Gambar 3 dibawah ini.

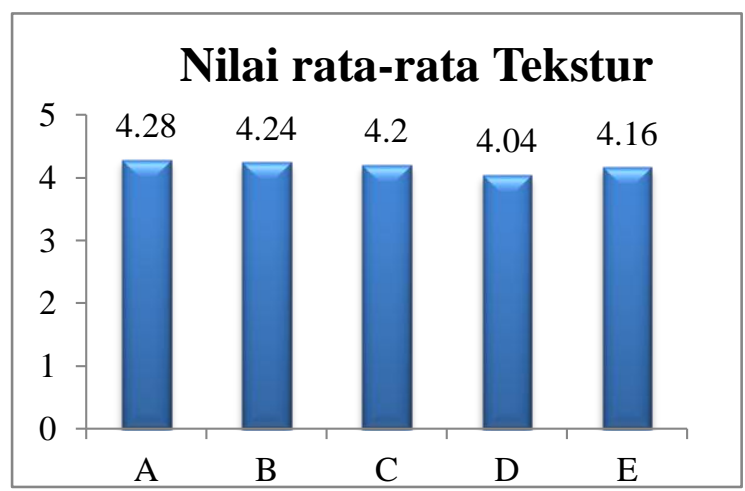

Gambar 3. Nilai rata-rata uji organoleptik terhadap tekstur kue semprong

Berdasarkan hasil analisis sidik ragam kue semprong dengan pencampuran tepung ubi ungu dan tepung terigu menunjukan nilai $\mathrm{F}$ hitung lebih kecil dari nilai $F$ tabel hal ini menunjukan pencampuran tepung ubi jalar ungu dan tepung terigu tidak memberikan pengaruh terhadap tekstur kue semprong. Tekstur yang dihasilkan kue semprong dengan pencampuran ubi jalar ungu dan tepung terigu adalah tekstur yang renyah.

Menurut Harijono (2012), kerenyahan dipengaruhi oleh jenis tepung yang mengandung pati tinggi dan serat kasar yang rendah. Kandungan pati tepung terigu adalah $68-78 \%$ sedangkan kandungan pati tepung ubi jalar ungu 56,53\%-72,03\% (Apriliyanti, 2010).

\section{Rasa}

Hasil uji organoleptik terhadap rasa kue semprong campuran tepung ubi jalar ungu dan tepung terigu berkisar antara 3,88 - 4,32 (suka) dapat dilihat pada Gambar 4 dibawah ini.

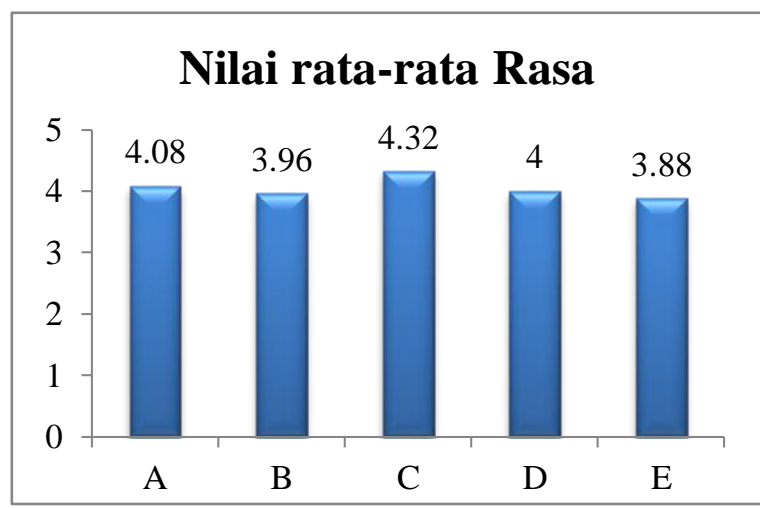

Gambar 4. Nilai rata-rata uji organoleptik terhadap rasa kue semprong

Berdasarkan hasil analisis sidik ragam kue semprong dengan pencampuran tepung ubi ungu dan tepung terigu menunjukan nilai $\mathrm{F}$ hitung lebih kecil dari nilai $F$ tabel hal ini menunjukan pencampuran tepung ubi jalar ungu dan tepung terigu tidak memberikan pengaruh terhadap rasa kue semprong.

Rasa kue semprong merupakan kontribusi dari berbagai komponen penyusunnya yakni gula, santan dan telur. Jumlah komponen-komponen tersebut tidak mengalami perubahan jumlah dalam formulasi kue semprong sehingga rasa yang dihasilkan menimbulkan kesan kesukaan pada tingkat yang sama. Seiring dengan Harijono (2012), rasa kue semprong dipengaruhi oleh perpaduan rasa yag ditimbulkan komponenkomponen seperti gula yang memberikan rasa manis, santan dan telur yang memberikan rasa gurih.

Berdasarkan hasil Uji Organoleptik kue semprong pencampuran tepung ubi jalar ungu dan tepung terigu yang dilakukan terhadap 25 panelis Mahasiswa Teknologi 
Pertanian, panelis menyukai keseluruhan perlakuan.

Tabel 3. Nilai rata-rata Uji Organoleptik Kue Semprong dengan Pencampuran Tepung Ubi Jalar Ungu dan Tepung Terigu

\begin{tabular}{ccccc}
\hline \multirow{2}{*}{ Komponen } & \multicolumn{3}{c}{ Nilai rata-rata } \\
\cline { 2 - 5 } A & Warna & Aroma & Tekstur & Rasa \\
\hline B & 4,0 & 4,08 & 4,28 & 4,08 \\
$\mathbf{C}$ & 3,72 & 3,92 & 4,24 & 3,96 \\
$\mathbf{D}$ & 3,88 & 4,0 & 4,2 & 4,32 \\
$\mathbf{E}$ & 3,64 & 3,92 & 4,04 & 4,0 \\
\hline
\end{tabular}

Nilai rata-rata tertinggi diperoleh pada perlakuan A dengan perbandingan $(10 \mathrm{~g}$ tepung ubi ungu $+90 \mathrm{~g}$ tepung terigu).

Jenis ujian yang dilakukan dalam uji organoleptik ini adalah metode hedonik tingkat kesukaan panelis terhadap warna, aroma, rasa, dan tekstur yang dihasilkan dari setiap perlakuan. Uji organoleptik dimaksudkan untuk mengetahui penilaian panelis terhadap produk yang dihasilkan (Rampengan dkk, dalam Suprianto 2015).

\section{Komposisi Proksimat}

Nilai gizi suatu produk makanan merupakan salah satu faktor penting yang harus di perhatikan untuk menjamin keamanan dari produk makanan tersebut. Analisis proksimat bertujuan untuk menentukan nilai gizi suatu produk pangan

yang meliputu. Kadar Air, Kadar Abu, Kadar Protein, Kadar Lemak, dan Karbohidrat.

\section{Kadar Air}

Hasil analisis yang dihasilkan bahwa kadar air kue semprong campuran tepung ubi jalar ungu dan tepung terigu berkisar antara 3,16\% - 3,77\%.

Berdasarkan hasil analisis sidik ragam terhadap kadar air kue semprong dengan pencampuran tepung ubi jalar ungu dan tepung terigu menunjukan nilai $\mathrm{F}$ hitung lebih besar dari nilai $\mathrm{F}$ tabel sehingga dilanjutkan dengan uji BNT. Hasil uji BNT 5\% menunjukan bahwa perlakuan A (10g tepung ubi jalar ungu + $90 \mathrm{~g}$ tepung terigu), E (90g tepung ubi jalar ungu $+10 \mathrm{~g}$ tepung terigu), $\mathrm{C}(50 \mathrm{~g}$ tepung ubi jalar ungu $+50 \mathrm{~g}$ tepung terigu), B (30g tepung ubi jalar ungu $+70 \mathrm{~g}$ tepung terigu), dan $\mathrm{D}$ (70g tepung ubi jalar ungu $+30 \mathrm{~g}$ tepung terigu) berbeda nyata satu sama lain.

Tabel 4. Nilai rata-rata Kadar Air Kue Semprong.

\begin{tabular}{cc}
\hline Perlakuan & Rata - rata Kadar Air (\%) \\
\hline A (10g Tepung ubi ungu + 90g Tepung terigu) & $3,16^{\mathrm{a}}$ \\
B (30g Tepung ubi ungu + 70g Tepung terigu) & $3,37^{\mathrm{d}}$ \\
C (50g Tepung ubi ungu + 50g Tepung terigu) & $3,31^{\mathrm{c}}$ \\
D (70g Tepung ubi ungu + 30g Tepung terigu) & $3,77^{\mathrm{e}}$ \\
E (90g Tepung ubi ungu + 10g Tepung terigu) & $3,21^{\mathrm{b}}$ \\
\hline
\end{tabular}


BNT $5 \%=0,03$

Beberapa hal yang dapat mempengaruhi kadar air yaitu jenis bahan dan komponen yang ada di dalamnya, serta cara dan kondisi pemanggangan seperti alat dan ketebalan bahan. Kadar air dalam kue semprong diperoleh dari pencampuran bahan baku tepung ubi jalar ungu dan tepung terigu yang memiliki kadar air pada tepung ubi jalar ungu 68,5gram dan pada tepung terigu 12,0gram.

\section{Kadar Abu}

Hasil analisis yang dihasilkan, ratarata kadar abu kue semprong campuran tepung ubi ungu dan tepung terigu berkisar antara $1,32 \%-2.09 \%$.

Berdasarkan hasil analisis sidik ragam terhadap kadar abu kue semprong dengan pencampuran tepung ubi jalar ungu dan tepung terigu menunjukan nilai $\mathrm{F}$ hitung lebih besar dari nilai $\mathrm{F}$ tabel sehingga dilanjutkan dengan uji BNT.

Semakin banyak tepung ubi ungu dan tepung terigu dalam pencampuran semakin tinggi jumlah kadar abu kue semprong. Seharusnya syarat mutu kue kering yang baik memiliki kadar abu di bawah 1,6 \% (SNI : 1992).

Peningkatan kadar abu yang dihasilkan setiap perlakuan diduga karena kandungan mineral dalam tepung ubi jalar ungu relatif tinggi. Tepung ubi jalar ungu mengandung fosfor sebesar $74 \mathrm{mg}$, zat besi 0,70 mg serta kalsium sebesar $29 \mathrm{mg}$ dalam 100 g, Mahmud dkk. (2009).

\section{Kadar Lemak}

Hasil analisis yang dihasikan, nilai rata-rata kadar lemak kue semprong dengan pencampuran tepung ubi jalar ungu dan tepung terigu berkisar antara $16,26 \%-20,95 \%$ (Tabel 6)

Berdasarkan hasil analisis sidik ragam terhadap kadar lemak kue semprong dengan pencampuran tepung ubi jalar ungu dan tepung terigu menunjukan nilai $\mathrm{F}$ hitung lebih besar dari nilai $\mathrm{F}$ tabel sehingga dilanjutkan dengan uji BNT. Hasil uji BNT 5\% menunjukan bahwa perlakuan D (70g tepung ubi jalar ungu $+30 \mathrm{~g}$ tepung terigu), B (30g tepung ubi jalar ungu $+70 \mathrm{~g}$ tepung terigu), A (10g tepung ubi jalar ungu $+90 \mathrm{~g}$ tepung terigu), C (50g tepung ubi jalar ungu + $50 \mathrm{~g}$ tepung terigu), dan $\mathrm{E}$ ( $90 \mathrm{~g}$ tepung ubi jalar ungu $+10 \mathrm{~g}$ tepung terigu) berbeda nyata satu sama lain.

Kue semprong memiliki kandungan lemak yang tinggi. Tingginya kadar lemak pada campuran tepung ubi jalar ungu dan tepung terigu disebabkan beberapa bahan tambahan yang mengandung lemak seperti susu, margarin dan santan. Penambahan santan dengan kepekatan lebih rendah menghasilkan kue semprong yang memiliki kadar lemak lebih rendah Harijono (2012).

Tabel 5. Nilai rata-rata Kadar Abu Kue Semprong.

\begin{tabular}{cc}
\hline Perlakuan & Rata - rata Kadar Abu (\%) \\
\hline A (10g Tepung ubi ungu + 90g Tepung terigu) & $1,32^{\mathrm{a}}$ \\
B (30g Tepung ubi ungu + 70g Tepung terigu) & $1,52^{\mathrm{b}}$ \\
C (50g Tepung ubi ungu + 50g Tepung terigu) & $1,64^{\mathrm{c}}$ \\
D (70g Tepung ubi ungu + 30g Tepung terigu) & $1,70^{\mathrm{d}}$ \\
E (90g Tepung ubi ungu + 10g Tepung terigu) & $2,09^{\mathrm{e}}$ \\
\hline
\end{tabular}

BNT 5\% $=0,03$ 
Tabel 6. Nilai rata-rata Kadar Lemak Kue Semprong

\begin{tabular}{cc}
\hline Perlakuan & Rata - rata Kadar Lemak (\%) \\
\hline A (10g Tepung ubi ungu + 90g Tepung terigu) & $19,14^{\mathrm{c}}$ \\
B (30g Tepung ubi ungu + 70g Tepung terigu) & $17,97^{\mathrm{b}}$ \\
C (50g Tepung ubi ungu + 50g Tepung terigu) & $19,59^{\mathrm{d}}$ \\
D (70g Tepung ubi ungu + 30g Tepung terigu) & $16,26^{\mathrm{a}}$ \\
E (90g Tepung ubi ungu + 10g Tepung terigu) & $20,95^{\mathrm{e}}$ \\
\hline
\end{tabular}

BNT 5\% $=0,02$

\section{Kadar Protein}

Hasil analisis yang dihasikan, nilai rata-rata kadar protein kue semprong dengan pencampuran tepung ubi ungu dan tepung terigu berkisar antara 7,06\% $8,95 \%$ (Table 7).

Berdasarkan hasil analisis sidik ragam terhadap kadar protein kue semprong dengan pencampuran tepung ubi jalar ungu dan tepung terigu menunjukan nilai $\mathrm{F}$ hitung lebih besar dari nilai $\mathrm{F}$ tabel sehingga dilanjutkan dengan uji BNT.

Pada dasarnya tepung ubi jalar ungu dan tepung terigu memilki kandungan protein yang rendah. oleh karena itu perlu adanya sumber protein lain yang dikonsumsi agar kebutuhan protein tercukupi. Tingginya kadar protein adalah akibat penambahan telur yang mengandung protein cukup tinggi.

\section{Kadar Karbohidrat}

Nilai rata-rata kadar karbohidrat kue semprong dengan pencampuran tepung ubi ungu dan tepung terigu berkisar antara $66,31 \%$ - 71,21\% (Tabel 8).

Berdasarkan hasil analisis sidik ragam terhadap kadar karbohidrat kue semprong dengan pencampuran tepung ubi jalar ungu dan tepung terigu menunjukan nilai $\mathrm{F}$ hitung lebih besar dari nilai $\mathrm{F}$ tabel sehingga dilanjutkan dengan uji BNT.

Hasil uji BNT 5\% menunjukan bahwa perlakuan E (90g tepung ubi jalar ungu + $10 \mathrm{~g}$ tepung terigu), C (50g tepung ubi jalar ungu $+50 \mathrm{~g}$ tepung terigu), A $(10 \mathrm{~g}$ tepung ubi jalar ungu $+90 \mathrm{~g}$ tepung terigu), B (30g tepung ubi jalar ungu + $70 \mathrm{~g}$ tepung terigu), dan $\mathrm{D}$ (70g tepung ubi jalar ungu $+30 \mathrm{~g}$ tepung terigu) berbeda nyata satu sama lain.

Tabel 7. Nilai rata-rata Kadar Protein Kue Semprong

\begin{tabular}{lc}
\hline Protein & Rata - rata Kadar Protein $(\%)$ \\
\hline A (10g Tepung ubi ungu + 90g Tepung terigu) & $8,72^{\mathrm{d}}$ \\
B (30g Tepung ubi ungu + 70g Tepung terigu) & $8,95^{\mathrm{e}}$ \\
C (50g Tepung ubi ungu $+50 \mathrm{~g}$ Tepung terigu) & $8,63^{\mathrm{c}}$ \\
D (70g Tepung ubi ungu + 30g Tepung terigu) & $7,06^{\mathrm{a}}$ \\
E (90g Tepung ubi ungu + 10g Tepung terigu) & $7,45^{\mathrm{b}}$ \\
\hline BNT 5\% $=0,02$ &
\end{tabular}


Tabel 8. Nilai rata-rata Kadar Karbohidrat Kue Semprong

\begin{tabular}{cc}
\hline Perlakuan & Rata - rata Karbohidrat $(\%)$ \\
\hline A (10g Tepung ubi ungu + 90g Tepung terigu) & $67,66^{\mathrm{c}}$ \\
B (30g Tepung ubi ungu + 70g Tepung terigu) & $68,19^{\mathrm{d}}$ \\
C (50g Tepung ubi ungu + 50g Tepung terigu) & $66,83^{\mathrm{b}}$ \\
D (70g Tepung ubi ungu + 30g Tepung terigu) & $71,21^{\mathrm{e}}$ \\
E (90g Tepung ubi ungu + 10g Tepung terigu) & $66,31^{\mathrm{a}}$ \\
\hline BNT 5\% $=0,01$ &
\end{tabular}

Kandungan karbohidrat kue semprong campuran tepung ubi jalar ungu dan tepung terigu relatif tinggi. Tingginya kandungan karbohidrat dalam kue semprong disebabkan oleh bahan baku yaitu tepung terigu yang memiliki kandungan karbohidrat tinggi juga tepung ubi jalar ungu yang merupakan sumber karbohidrat.

Hasil analisis keseluruhan rata-rata kandungan kimia pada kue semprong dengan pencampuran tepung ubi jalar ungu dan tepung terigu dapat dilihat pada Gambar 5.

Berdasarkan hasil analisi kandungan kimia pada kue semprong campuran tepung ubi jalar ungu dan tepung terigu, kandungan karbohidrat adalah kandungan tertinggi dengan nilai rata-rata $66,31 \%$ $71,21 \%$ dan kadar abu dengan nilai ratarata $1,32 \%-2,09 \%$ yang merupakan kandungan terkecil dari keseluruhan kandungan kimia pada kue semprong campuran tepung ubi jalar ungu dan tepung terigu.

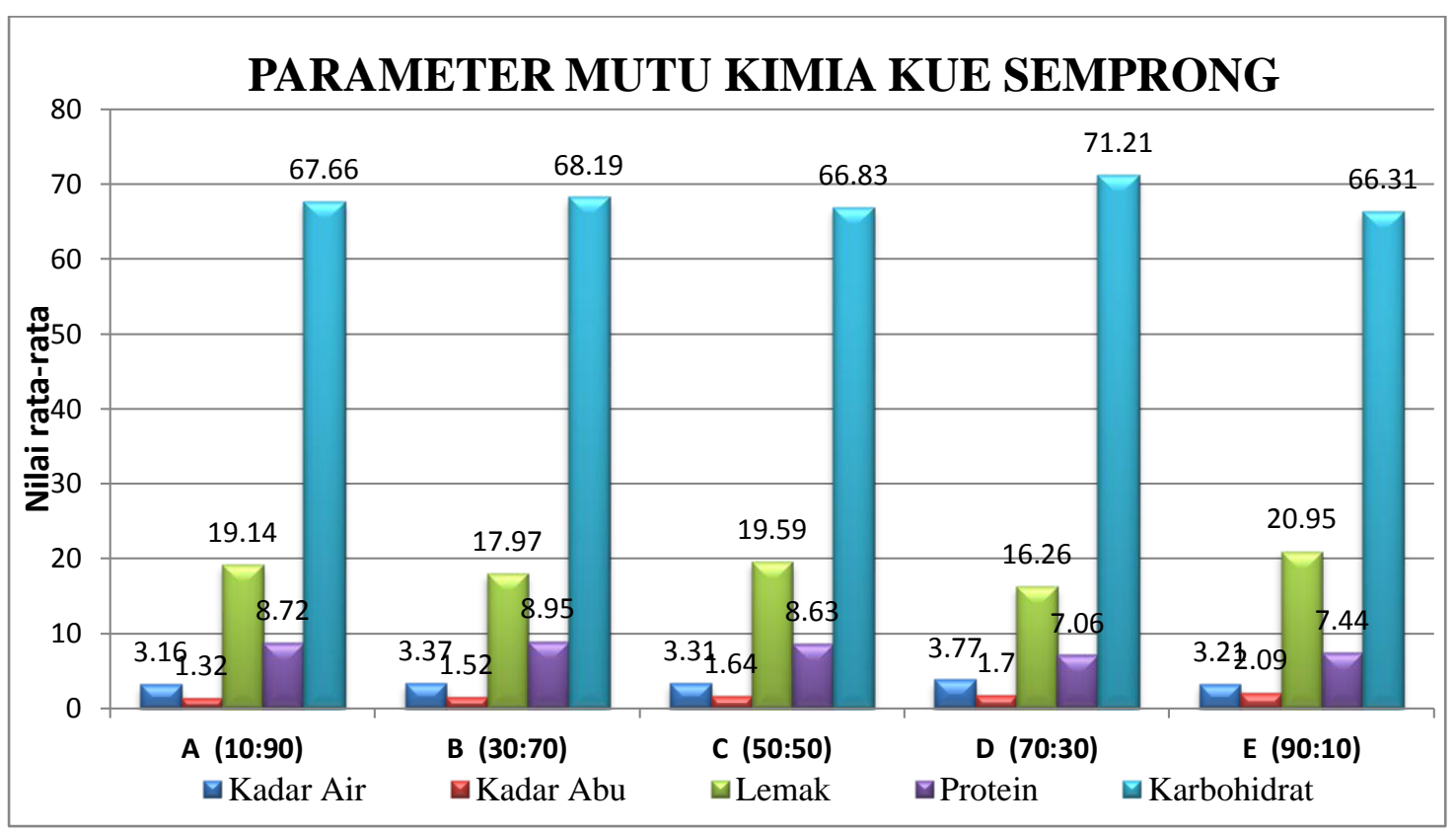

Gambar 5. Rata-rata Kandungan Kimia Kue Semprong dengan Pencampuran Tepung Ubi Jalar Ungu dan Tepung Terigu. 


\section{KESIMPULAN}

Berdasarkan analisis tingkat kesukaan panelis serta analisi kimia pada kue semprong, dapat disimpulkan bahwa formulasi kue semprong dengan campuran $10 \%$ tepung ubi jalar ungu dan $90 \%$ tepung terigu dengan warna $(4,0)$, aroma $(4,08)$, tekstur $(4,28)$, rasa $(4,08)$ disukai panelis dengan kadar air 3,16\%, kadar abu $1,32 \%$, kadar lemak 19,14\%, kadar protein $8,72 \%$ dan karbohidrat $67,66 \%$.

\section{DAFTAR PUSTAKA}

Apriliyanti T. 2010. Kajian Sifat Fisikokimia Dan Sensori Tepung Ubi Jalar Ungu (Ipomoea batatas blackie) Dengan Variasi Proses Pengeringan. Skripsi. Fakultas Pertanian. Universitas Sebelas Maret.

Gisslen, W. 2013. Professional Baking. 6th ed. Hoboken, New Jersey: Jhon Wiley \& Sons, Inc.

Harijono, Susanto, W.H. dan Ismet, F. 2012. Studi Penggunaan Proporsi Tepung (Sorgum Ketan Dengan Beras Ketan) dan Tingkat Kepekatan Santan Yang Berbeda Terhadap Kualitas Kue Semprong. Fakultas Teknologi Pertanian, Universitas Brawijaya, Malang.

Kartika B., Hastuti, P. dan W. supartomo. 1988. Pedoman Uji Inderawi Bahan Pangan. PAU Pangan dan Gizi. Yogyakarta.

Kumalaningsi S. 2008. Antioksidan, Sumber \& Manfaatnya. Antioxidant Center Online. Home page on-line.Available from http://antioxidantcenter.com/index.php/Antioksidan/ 3.-Antioksidan-SumberSumber-

Manfaatnya.html; Internet; accessed 3 Juni 2017.

Mahmud M. K., Hermana, N.A. Zulfianto, I. Ngadiarti, R.R. Apriyantono, B. Hartati, Bernadus, dan Tinexcelly.
2009. Tabel Komposisi Pangan Indonesia.PT Elex Media Komputindo. Kompas Gramedia. Jakarta.

Murtiningsih dan Suyanti, 2011. Membuat Tepung Umbi dan Variasi Olahannya.Jakarta: AgroMedia Pustaka.

Pokorny J, N. Janishlieva, N. dan M. Gordon. 2001. Antioxidant in Food. CRC Press Cambridge. Inggris.

Richana, Nur. 2012. Ubi Kayu dan Ubi Jalar, Botani - Budidaya, Teknologi Proses. Teknologi Pasca Panen. Bogor : Nuansa.

Shahidi, F.; and M. Naczk. (1995). Food Phenolics : Sources, Chemistry, Effects, and Applications. Technomic Publishing Company. USA

Silalahi, J. 2006. Makanan Fungsional. Kanisius.Yogyakarta.

Suprianto. A. B. (2015). Subtitusi tepung kacang hijau (Phaseolus radiathus L) dalam pembuatan biscuit kimpul (Xantosoma sagittifolium (L) Schott). Skripsi Fakultas Pertanian, Jurusan Teknologi Pertanian UNSRAT MANADO.

Wijayanti. Z., dan Burhan. 2010. Minyak atsiri dari kulit batang cinnamomum burmanni (kayu manis) Dari famili lauraceae sebagai insektisida alami, antibakteri, dan antioksidan. Laboratorium Kimia Organik Jurusan Kimia Fakultas Matematika dan Ilmu Pengetahuan Alam. Institut Teknologi Sepuluh Nopember. Surabaya.

Winarno, F. G., 2004. 1984. Kimia Pangan dan Gizi. PT. Gramedia PustakaUtama, Jakarta. 